\title{
Peculiarities of Implementation of Insurance Foundations in the Social Support of Citizens in Russian Regions (The Case of the Republic of Tatartstan)
}

\author{
N. G. Bagautdinova ${ }^{1}$, A. V. Sarkin ${ }^{1}$, B. A. Averyanov ${ }^{1} \&$ A. A. Gilmanova ${ }^{2}$ \\ ${ }^{1}$ Kazan Federal University, Institute of Management, Economics and Finance, Kazan, Russia \\ ${ }^{2}$ Kazan Federal University, Institute of Language, 420008, Kazan, Russia \\ Correspondence: B. A. Averyanov, Kazan Federal University, Institute of Management, Economics and Finance, \\ Kazan, 420008, Russia. Tel: 7-906-321-9099. E-mail: verkbund@gmail.com
}

Received: March 19, 2015 Accepted: March 31, 2015 Online Published: April 30, 2015

doi:10.5539/ass.v11n11p391

URL: http://dx.doi.org/10.5539/ass.v11n11p391

\begin{abstract}
The article analyzes financial condition of OJSC "Kazanorsintez" using a modified factor model of "DuPont" company. This approach helped to define the guidelines aimed at perfecting the incompany profit and efficiency planning, which allows to use resources rationally and to achieve maximal results. The conducted research indicated the company's unimproved opportunities, the implementation of which suggests the necessity of lowering current costs as well as further turnover acceleration by means of optimization of their structure, increasing efficiency in using all resources, strengthening financial stability and paying capacity, which will provide additional profit markup owing to profitability of sales.
\end{abstract}

Keywords: financial condition of a company, financial soundness and solvency of a company, return on equity, factor model of "DuPont" company, incompany planning of profit and efficiency

\section{Introduction}

In the current context, the performance of every economic entity is the subject of attention for a wide range of members of market relations, who are interested in the results of its functioning. In order to provide steadiness of financial and economic development of a company, the managerial stuff should be feasibly able to assess the situation in their own company as well as the one of the existing prospective competitors. The assessment of financial results is the pivotal characteristics of company's activity. Company's effective performance in modern-day market conditions is possible only on the basis of perfection of incompany profit planning and efficiency, which allows to use resources rationally and to achieve maximal results. Analytical profit and efficiency diagnostics of a company allows to reveal a considerable number of development trends and is aimed at indicating further successful development of a company. It indicates the drawbacks in business activity and reveals the reserves of profit and efficiency markup. In this regard, the development of factor models to analyze certain profitability performance profiles acquire certain theoretic and practical relevance, as well as their practical approval taking into consideration specific features of functioning of an enterprise. The works of many Russian (Safiullin, Samigullin, \& Safiullin, 2013; Sarkin, Bagautdinova, \& Averianov, 2013) and foreign authors (Ansoff, 1957; Averianov, Bagautdinova, \& Sarkin, 2013; Black \& Scholes, 1973; Freeman, 1999; Levy \& Marshall, 1990; Paulsen, 1993; Geiger, Ritchie, \& Marlin, 2006; Steiner, 1980) were devoted to this aspect of strategic management planning, though the issue of applying the given models to functioning of Russian companies still remains under-investigated.

\section{Methodology}

Economic literature recommends different factor models to analyze profitability performance profiles, from basic two-factor models to multifactor ones. By means of them, cause-and-effect relations between financial results and index of company's financial state can be revealed. The most famous methods of factor analysis include hierarchical structure of financial ratios, which allows to demonstrate several aspects of company's activity within one scheme or a table concisely, but visually. It also helps to comprehend the interconnection between liquidity, financial structure and efficiency of a company. The use of strictly determined factor models is quite an effective method of assessment: one of the variants of a similar analysis is performed with the help of modified factor model of DuPont Company. (Brigham, \& Houston, 2012) 
In 1919 the specialists of DuPont company (The DuPont System of Analysis) offered the scheme of factor analysis. The DuPont corporation factor model was the first to correlate several factors and present them in the form of a triangle structure, on the top of which is the overall capital's return on revenue ROA as the main factor characterizing the efficiency of assets, invested to the company operation. At the bottom of the structure there are two factor indices - profitability of sales NPM and resource productivity TAT.

The modified DuPont model looks as follows:

$$
\rho_{\text {cк }}=(\text { Пч / Врп)*(Врп/Б)*(Б/П’'III), }
$$

where $\rho_{\mathrm{c \kappa}}$ is return on equity; Пч is net profit, RUB; П'III is company's own resources, RUB; Bрп is sales revenue, RUB; $\mathrm{B}$ is company's asset value, RUB

Formula (1) can also be presented as follows:

$$
\rho_{\text {ск }}=\rho_{\text {пр }} * \mathrm{f} * \mathrm{k}
$$

where $\rho_{\text {пр }}$ is profitability of sales estimated by net profit ( $\rho_{\text {пр }}=\Pi$ І / Врп), or profit rate; $\mathrm{f}$ is return on assets estimated by revenue $(\mathrm{f}=\mathrm{Bp} / \mathrm{5})$, or the rate of turnover of overall corporate assets; $\mathrm{k}$ - is capitalization ratio which reflects the correlation between non-borrowed and borrowed funds $(k=5 / \Pi ' I I I)$, or financial leverage.

DuPont Company's factor model is used for factor analysis of return on equity. It establishes interconnection between return on equity and main financial indicators of a company's profitability of sales, asset turnover and financial leverage. In every particular case the model determines factors which have the biggest impact on the size of the return on equity. From the model presented we can see that return on equity depends on three factors: profitability of sales, asset turnover and the structure of advanced capital. The significance of defined factors is explained by the fact that they generalize all aspects of company's financial and economic activity, its statics and dynamics. Modified factor model vividly demonstrates that the company's return on equity and its financial soundness are inversely related. When the company's own resources increase, its profitability declines, but company's financial soundness and solvency generally grow up.

\section{Results}

As part of the study, the modified factor model was used to analyze financial situation of OJSC "Kazanorgsintez" as one of the largest chemical companies of the Russian Federaion. The company produces $38 \%$ of the total Russian output of polyethylene and it is one of its major exporters (OJSC "Kazanorgsintez" company's official website). Table 1 presents annual report data on profit and loss, Table 2 gives statistics from the company's balance sheet.

Table 1. OJSC "Kazanorgsintez" profit and loss report data, 2013, thousand RUB (Note 1)

\begin{tabular}{ccc}
\hline Indices & 2012 & 2013 \\
\hline Revenue & 45460303 & 46134205 \\
Net profit & 3284618 & 2157140 \\
\hline
\end{tabular}

Table 2. OJSC “Kazanorgsintez” balance sheet data, 2011- 2013, thousand RUB (Note 2)

\begin{tabular}{lccc}
\hline \multicolumn{1}{c}{ Indices } & 2011 & 2012 & 2013 \\
\hline Total fixed assets & 35852368 & 31844769 & 29080644 \\
Total current assets & 7597663 & 8053199 & 7742380 \\
Total equity and reserve & 8175234 & 11358610 & 12509735 \\
Total non-current liabilities & 31597287 & 23441952 & 18218259 \\
Total current liabilities & 3677510 & 5097406 & 6095030 \\
Balance & 43450031 & 39897968 & 36823024 \\
\hline
\end{tabular}

Above mentioned table data is used for profitability factor analysis of OJSC "Kazanorgsintez" (Table 3). When calculating indices of profitability, arithmetic means of the balance sheet were used.

As can be seen from Table 3, not all initial indices have increased to a greater or lesser degree. Considerable increase can be observed in the average cost of owned capital (for 22.2\%) and the asset turnover (for 10.2\%). Leverage ratio has decreased for 1.05 units or $24.7 \%$, which suggests the decline in the share of borrowed current assets of OJSC "Kazanorgsintez" in 2013.

We use a three-factor model (formula 1) and the method of absolute distinction to carry out factor analysis of OJSC "Kazanorgsintez" company's return on equity in 2013. The calculation data is presented in Table 4. 
Table 3. Benchmark data for factor analysis of OJSC “Kazanorgsintez” company’s own capital, 2013

\begin{tabular}{lccccc}
\hline \multicolumn{1}{c}{ Indices } & $\begin{array}{c}\text { Conventional } \\
\text { signs }\end{array}$ & 2012 & 2013 & $\begin{array}{c}\text { Variables } \\
(+;-)\end{array}$ & $\begin{array}{c}\text { Growth } \\
\text { rate, \% }\end{array}$ \\
\hline Net profit, mln RUB & Пч & 3284.6 & 2157.1 & -1127.5 & -34.3 \\
Sales revenue, mln RUB & $\mathrm{B}$ & 45460.3 & 46134.2 & 673.9 & 1.5 \\
Average asset value, mln RUB & $\mathrm{A}$ & 41674.0 & 38360.5 & -3313.5 & -8.0 \\
Average cost of owned capital, mln RUB & $\mathrm{CK}$ & 9766.9 & 11934.2 & 2167.3 & 22.2 \\
Profitability of sales, (Пч/B), units & $\mathrm{a}$ & 0.07 & 0.05 & -0.03 & -35.3 \\
Asset turnover, (B/A), units & $\mathrm{b}$ & 1.09 & 1.20 & 0.11 & 10.2 \\
Leverage ratio (A/CK), units & $\mathrm{c}$ & 4.27 & 3.21 & -1.05 & -24.7 \\
Return on equity, (Пч/CK), units & $\mathrm{y}$ & 0.34 & 0.18 & -0.16 & -46.3 \\
\hline
\end{tabular}

Table 4. Calculation of factors impact on OJSC “Kazanorgsintez” company's return on equity in 2013, units

\begin{tabular}{ccc}
\hline Factors & Calculation & Factor's impact \\
\hline $\mathrm{P} / \mathrm{N}(\mathrm{a}) \Delta \mathrm{Va}_{\mathrm{a}}$ & $\Delta \mathrm{a} * \mathrm{~b} 0^{*} \mathrm{c} 0$ & -0.119 \\
$\mathrm{~N} / \mathrm{A} \mathrm{(b)} \Delta \mathrm{Yb}$ & $\mathrm{a} 1{ }^{*} \Delta \mathrm{b}^{*} \mathrm{c} 0$ & 0.022 \\
$\mathrm{~A} / \mathrm{CK}(\mathrm{c}) \Delta \mathrm{Y}_{\mathrm{c}}$ & $\mathrm{a} 1{ }^{*} \mathrm{~b} 1 * \Delta \mathrm{c}$ & -0.059 \\
Total impact & & -0.156 \\
\hline
\end{tabular}

As can been observed from the data presented, the decrease in the return on equity to 0.16 units took place as the result of impact from all factors. The decrease in profitability of sales led to the decrease of the return on equity for 0.119 units. Acceleration of the asset turnover to 0.11 gave rise to the growth of return on equity to 0.022 units, and the reduction of the leverage ratio resulted in the decrease of return on equity to 0.059 units.

The analysis of the results obtained indicates that all factors can be the reserve for the return on equity growth. It should be noted that the decrease of borrowed funds (lower leverage ratio) also leads to lower return on equity level. Thus, the company receives a commission in the form of its capital growth for the financial risk it takes with new borrowed funds. When using this reserve it should be taken into account that increased dependence on external borrowings can considerably deteriorate financial position in case of sales deceleration. Furthermore, high leverage ratio may lead to difficulties with receiving new loans. However, it should be taken into account that acceleration of current asset turnover has positive impact on profit only to a certain extent, which is determined by demands of maintaining liquidity. With insufficient level of working assets and their extremely high turnover, there develops a real risk of company's liquidity loss, scarcity of funds to continue operating activity, loss of revenue and profit. With low turnover of working assets, the company has larger amount of finance and, as a result, minimal risk of liquidity loss. Thus, the return on assets decreases because a company loses paper profit. With very high working assets turnover, their level may become insufficient to maintain liquidity, which also increases risks and leads to loss of profit. That's why we should search for a compromise which provides sufficient level of profit with acceptable level of liquidity risk.

Analytical model of return on equity should be adapted to financial statements, used as information basis of analysis. To accomplish this, the following guidelines should be applied:

A) Factors which are introduced in the judicial part (1), should exist in the company's financial statement.

B) Indices which are formed in the first part should characterize relevant aspects for managing company's activity. It is also recommended that these indices have economic sense, are well-known and have been used in economic activity before.

The main drawback of formula (1) is the definition of profitability of sales based on net profit. As a result, two incomparable values are compared - net profit (Пч) and sales revenue (Врп). Therefore, it is not correct to use this index in Russian practice.

In our opinion, the following return on equity five-factor model derived from DuPont method is the most suitable for the present-day Russian financial statement:

$$
\rho_{\mathrm{ck}}=(\Pi ч / \Pi д н о) *(П д н о / П р п) *(П р п / В р п) *(В р п / Б) *(Б / П ’ \mathrm{III})
$$

where Пдно is pretax profit, Прп is sales profit.

In formula (3):

A) The (Пч/Пдно) constituent reflects the balance-sheet and net profit ratio. It characterizes "rigidity" of taxation system's financial result. It is sometimes called "tax burden ratio"; 
В) The (Пдно/Прп) constituent reflects the ratio of balance-sheet (total) company profit and sales profit, that is to say, the profit from the company' score activity. It characterizes the participation of non-productive activity in forming financial result;

C) The (Прп/Врп) constituent reflects profitability of sales, defined according to the methodology applied in Russian practice;

D) The (Bрп/Б) constituent reflects, as it was mentioned above, return on assets, determined from sales revenue. It also characterizes company assets rate of turnover (assets turnover ratio).

E) The (Б/П'III) constituent reflects, as it was mentioned above, the ratio of company's own and borrowed financing sources, which is the value, reciprocal to equity to total assets ratio. In financial management this index is called "capitalization ratio" and characterizes the rate of business risks - the higher is capitalization ratio, the riskier a business is, as the share of borrowed financial sources and the share of company's own sources is lower in the structure of equities.

We use this model to investigate return on assets of OJSC "Kazanorgsintez". Benchmark data for analysis is given in Table 5.

Table 5. Benchmark data for factor analysis of return on assets of OJSC "Kazanorgsintez" in 2012-2013

\begin{tabular}{lccccc}
\hline \multicolumn{1}{c}{ Indices } & $\begin{array}{c}\text { Conventional } \\
\text { signs }\end{array}$ & $\begin{array}{c}2012 \\
\text { год }\end{array}$ & $\begin{array}{c}2013 \\
\text { год }\end{array}$ & $\begin{array}{c}\text { Variables } \\
(+;-)\end{array}$ & $\begin{array}{c}\text { Growth } \\
\text { rate, \% }\end{array}$ \\
\hline Net profit, mln RUB & Пч & 3284.6 & 2157.1 & -1128 & -34.3 \\
Sales revenue, mln RUB & $\mathrm{B}$ & 45460.3 & 46134.2 & 673.9 & 1.5 \\
Average asset value, mln RUB & $\mathrm{A}$ & 41674 & 38360.5 & -3314 & -8 \\
Average cost of working assets, mln RUB & $\mathrm{OA}$ & 7825.4 & 7897.8 & 72.4 & 0.9 \\
Average current liabilities & KO & 4387.6 & 5596.2 & 1208.6 & 27.5 \\
Profitability of sales, (Пч/B), units & $\mathrm{a}$ & 0.07 & 0.05 & -0.02 & -28.6 \\
Working assets turnover, (B/OA), units & $\mathrm{b}$ & 5.81 & 5.84 & 0.03 & 0.6 \\
Working capital ratio (OA/KO), units & $\mathrm{c}$ & 1.78 & 1.41 & -0.37 & -20.9 \\
Current liabilities share in assets (КО/A), unit & $\mathrm{d}$ & 0.11 & 0.15 & 0.04 & 38.6 \\
Return on assets, (П/A), units & $\mathrm{y}$ & 0.08 & 0.06 & -0.02 & -28.7 \\
\hline
\end{tabular}

The data from Table 5 suggests that the return on assets decreased to 0.02 units, the growth rate became $-28.7 \%$. This happened as the result of exceedance in the net profit rate of growth $(-34.3 \%)$ over assets growth rate $(-8 \%)$. The share of current liabilities in assets increased to $38.6 \%$. The working capital turnover increased to 0.03 . With the help of absolute distinction method let's inquire the impact of factors changes to the company's return on assets (Table 6).

Table 6. Calculation of factors' impact on the return on assets in OJSC "Kazanorgsintez"

\begin{tabular}{ccc}
\hline Factors & Calculation & Factor's impact \\
\hline П/В (a) $\Delta \mathrm{Ya}_{\mathrm{a}}$ & $\Delta \mathrm{a} * \mathrm{~b} 0^{*} \mathrm{c} 0 * \mathrm{~d} 0$ & -0.022 \\
$\mathrm{~B} / \mathrm{OA} \mathrm{(b)} \Delta \mathrm{Yb}$ & $\mathrm{a} 1^{*} \Delta \mathrm{b}^{*} \mathrm{c} 0 * \mathrm{~d} 0$ & 0.000 \\
$\mathrm{OA} / \mathrm{KO}(\mathrm{c}) \Delta \mathrm{Yc}$ & $\mathrm{a} 1^{*} \mathrm{~b} 1^{*} \Delta \mathrm{c} * \mathrm{~d} 0$ & -0.011 \\
$\mathrm{KO} / \mathrm{A}(\mathrm{d}) \Delta \mathrm{Yd}$ & $\mathrm{a} 1^{*} \mathrm{~b} 1^{*} \mathrm{c} 1^{*} \Delta \mathrm{d}$ & 0.017 \\
General impact & & -0.16 \\
\hline
\end{tabular}

As can be seen, the positive impact on the changes in return on assets was exerted by deceleration of working assets turnover and decrease in the share of current liabilities in assets. This surpassed the negative effect from increasing the level of profitability of sales and working capital ratio. As a result, return on assets decreased in the period of report to 0.016 units. According to this model, in the long term financial analysts should draw attention to deceleration of working assets turnover.

In reliance with the obtained results, top-management may work out proposals on preventing the influence of negative trends and more effective use of detected reserves in the future. These findings indicate the presence of open chances, which the company should reveal and take into account in the future, providing additional profit markup by means of profitability of sales growth, by reducing operating expenses as well as further acceleration of assets turnover by means of optimization of their structure, increased efficiency in using all resources, 
strengthening financial viability and solvency and so on. Besides, analytical studies show that the great impact on management efficiency level is produced by outside factors, such as currency rate, inflation etc. That is why the company management should direct its efforts to the use of internal reserves. Also, to refine the financial condition and to perfect the organization of the company's property assets, OJSC "Kazanorgsintez" may be offered the following ways of assets turnover acceleration: to reduce the duration of production cycle by means of intensification of production (the use of new technologies, mechanical operations and automation of production processes, increase in the level of performance, more intense use of manufacturing facilities, labour and physical resources etc.), to improve the organizing of material and technical supplies in order to supply manufacturing process with necessary material resources continuously and reduce time of keeping capital assets in stocks; to accelerate the process of product shipping and processing accounting documents, reducing the time of fixation of funds in debts receivable; increasing the level of market research, directed to the increase of sales promotion from a producer to a sales promotion, namely the study of effective demand, sales markets, verification of business plans and sales of products of appropriate output and range etc.

\section{Results}

Financial position of OJSC "Kazanorgsintez" is quite stable, which can be proved by the indices of return on equity and return on assets. For this reason, there are no obvious obstacles to hinder implementing strategic purposes of OJSC "Kazanorgsintez", namely its establishing as a leader among petrochemical companies by means of new market development, diversification its activity, providing delivery reliability.

\section{References}

Ansoff, I. (1957). Strategies for Diversification. Harvard Business Review, 35(5), 113-124.

Averianov, B. A., Bagautdinova, N. G., \& Sarkin, A. V. (2013). Estimation of manufacturing enterprise development risks in process of operational activity. World Applied Sciences Journal, 27(13), 202-206.

Black, F., \& Scholes, M. (1973). The Pricing of Options and Corporate Liabilities. Journal of Political Economy.

Brigham, E. F., \& Houston, J. F. (2012). Fundamentals of Financial Management (with Thomson ONE Business School Edition).

Freeman, C. (1999). The economics of industrial innovations. Cambridge, MIT Press.

Geiger, S. W., Ritchie, W. J., \& Marlin, D. (2006). Strategy / Structure Fit and Firm Performance. Organization Development Journal, 7. Copyright O. D. Institute Summer 2006.

Levy, H., \& Marshall, S. (1990). Capital investment and financial decisions. New Jersey; London: Prentice-Hall, Englewood Cliffs.

OJSC “Kazanorgsintez” company's official website. Retrieved from http://www.kazanorgsintez.ru/

Paulsen, J. (1993). Risk theory in a stochastic environment. J. Stochastic Process. Appl., 21, 327-361.

Safiullin, M. R., Samigullin, I. G., \& Safiullin, L. N. (2013). Model of Management of Competitiveness of a Machine-building Complex. World Applied Sciences Journal, 27(13), 212-216.

Sarkin, A. V., Bagautdinova, N. G., \& Averianov, B. A. (2013). Formulation of development strategies of machinery building complex enterprises and estimation of their implementation efficiency. World Applied Sciences Journal, 27(13), 170-173.

Steiner, G. A. (1980). Strategic Planning. NY: The Free Press.

\section{Notes}

Note 1. OJSC “Kazanorgsintez" company's annual report (digital resource). The company's official website http://www.kazanorgsintez.ru/

Note 2. Ibid.

\section{Copyrights}

Copyright for this article is retained by the author(s), with first publication rights granted to the journal.

This is an open-access article distributed under the terms and conditions of the Creative Commons Attribution license (http://creativecommons.org/licenses/by/3.0/ 